\title{
Plant Ageing, a Counteracting Agent to Xenobiotic Stress
}

\author{
David Delmail 1,2 and Pascal Labrousse ${ }^{2}$ \\ 1University of Rennes 1, Lab. of Pharmacognosy \& Mycology, \\ UMR CNRS 6226 SCR/PNSCM, Rennes \\ 2 University of Limoges, Lab. of Botany \& Cryptogamy, \\ GRESE EA 4330, Limoges \\ France
}

\section{Introduction}

A xenobiotic can be defined as any chemical or other substance that is not normally found in the ecosystems or that is present at concentrations harmful to all biological organisms. This general definition could be applied to anthropogenic and naturally occurring constituents. Organic contaminants can include pesticides, solvents and petroleum products. Inorganic xenobiotics include heavy metals, nonmetals, metalloids, radionuclides and simple soluble salts (Schwab, 2005).

Indeed, after absorption in plant cell, these toxics induce a broad range of disturbances like competition between elements. But the main effect remains the oxidative stress which disrupts many physiological pathways. Reactive oxygen species which initiate the oxidation are produced through several mechanisms in all cell compartments (Delmail et al., 2009; Thompson et al., 1987). Some reactive oxygen species are less deleterious to the plant cell than others but they can act as initiator of the production of more toxic compounds (Delmail et al., 2011c, 2011d).

To prevent from the production of reactive oxygen species, plants can use the senescence process to eliminate the xenobiotics from their organisms. Toxic compounds like radionuclides can be sequestrated by metallothioneins preferentially in vacuoles of specific organs like trichomes and old leaves. Indeed, morphological structures as non-glandular trichomes which are not implied in any physiological process, could store many xenobiotics. Moreover, potentially abscised organs as mature leaves are used to eliminate toxics from the living parts to protect the young organs from any disturbance of the photosynthetic pathways (Delmail et al., 2011c, 2011d).

This chapter will focus on xenobiotics having anthropogenic origins and will address organic and inorganic xenobiotics. Moreover, the origin of the oxidative stress induced by the xenobiotic assimilation, its consequence on the ageing of morphological, physiological and cellular patterns, as well as the functioning of antioxidant pathways, the implication of scavengers and the role of the senescence in reducing the oxidative disturbance, will be discussed in this chapter. 


\section{The xenobiotics}

A xenobiotic (from the Greek xenos "stranger" and biotic "related to living beings") is a biological (Qiu et al., 2002), physical (Sacco et al., 2004) or chemical disturbance which above a certain degree, and in certain environmental conditions, could lead to toxic effects on a part or the whole ecosystem. It implies that a xenobiotic acts as a pollutant or a contaminant of one or several compartments of the natural environments (atmosphere, lithosphere and hydrosphere) and of biological organisms among the biosphere. This compound disrupts the ecosystem functioning above the limit of tolerance.

The pollution introduced directly or indirectly by humans in all natural compartments, could have prejudicial consequences on its own species and others, on biological resources, on climates and on infrastructures (Delmail, 2007). This impact depends on the type of pollution as it could be distinguished the pollution of proximity and the regional/global pollution (Delmail et al., 2011a; Ritter et al., 2002). The first one is constituted by factory smokes, fumes, sewer gas, etc. and it is directly produced by an anthropogenic source. The second one results from more complex and diverse physicochemical phenomenon (e.g. ozone synthesis in troposphere, acid rains, greenhouse effect).

The xenobiotics could be classified according to their nature (solid, liquid, gas, mineral, organic), their radiation ( $X$, ultraviolet, infrared, radioactivity) and their origin (natural, synecological, autoecological, chemical, industrial) (Fig. 1). They may be also distinguished depending on their environmental targets (air, soil, and water), their biological targets (e.g. plants, fungi, mammals, invertebrates) and their cytotoxicity (e.g. cell types, organites). Their mode of action brings also information as some xenobiotics have an acute (death) or chronic toxicity (e.g. carcinogenesis, mutagenesis), or synergistic effect on organisms. They could be toxic at infinitesimal concentrations (micropollutants) or at a more concentrated range (macropollutants) (Delmail et al., 2010; Delmail et al., 2011b). Moreover, their effects have different duration of action: they could be degradable or persistent, or have a half-life like radioelements from several microseconds to many thousands of years.

Ecological exposure to environmental stressors occurs when a xenobiotic in a form that is bioavailable, reaches an organism. In order to be bioavailable, a xenobiotic must reach a location on or in an organism where it can cause an effect. The notion of phytoavailability defines the fraction of a bioavailable compound which could be absorbed by roots (Hinsinger et al., 2005).

The phytoavailability of xenobiotics is strongly correlated to the concentrations of contaminant species that occurred in the natural environments (Kabata-Pendias \& Pendias, 2000). It is also linked to the physicochemical properties of the environment, the plant taxon and the xenobiotic considered. Thus, the phytoavailability is dependent from several parameters allowing the transfer from aerial, solid or aqueous phase to the plant: the availability (or chemical mobility), the accessibility (or physical mobility) and the assimilation (or biological mobility) (Hinsinger et al., 2005).

The xenobiotics could be observed under free forms depending on environmental conditions, but in many cases they may interact with different elements from the environments which will have an influence on its behavior. They could be included in primary minerals originated from the rock crystallization, or in secondary minerals 
developed from primary ones after oxidation and hydrolysis processes. Moreover, they may be adsorbed on the organic matter in soils and waters, or on microorganisms (which could also absorb and accumulate them). Associations between colloids and xenobiotics could be observed in all natural compartments as a colloidal system may be solid, liquid or gaseous.

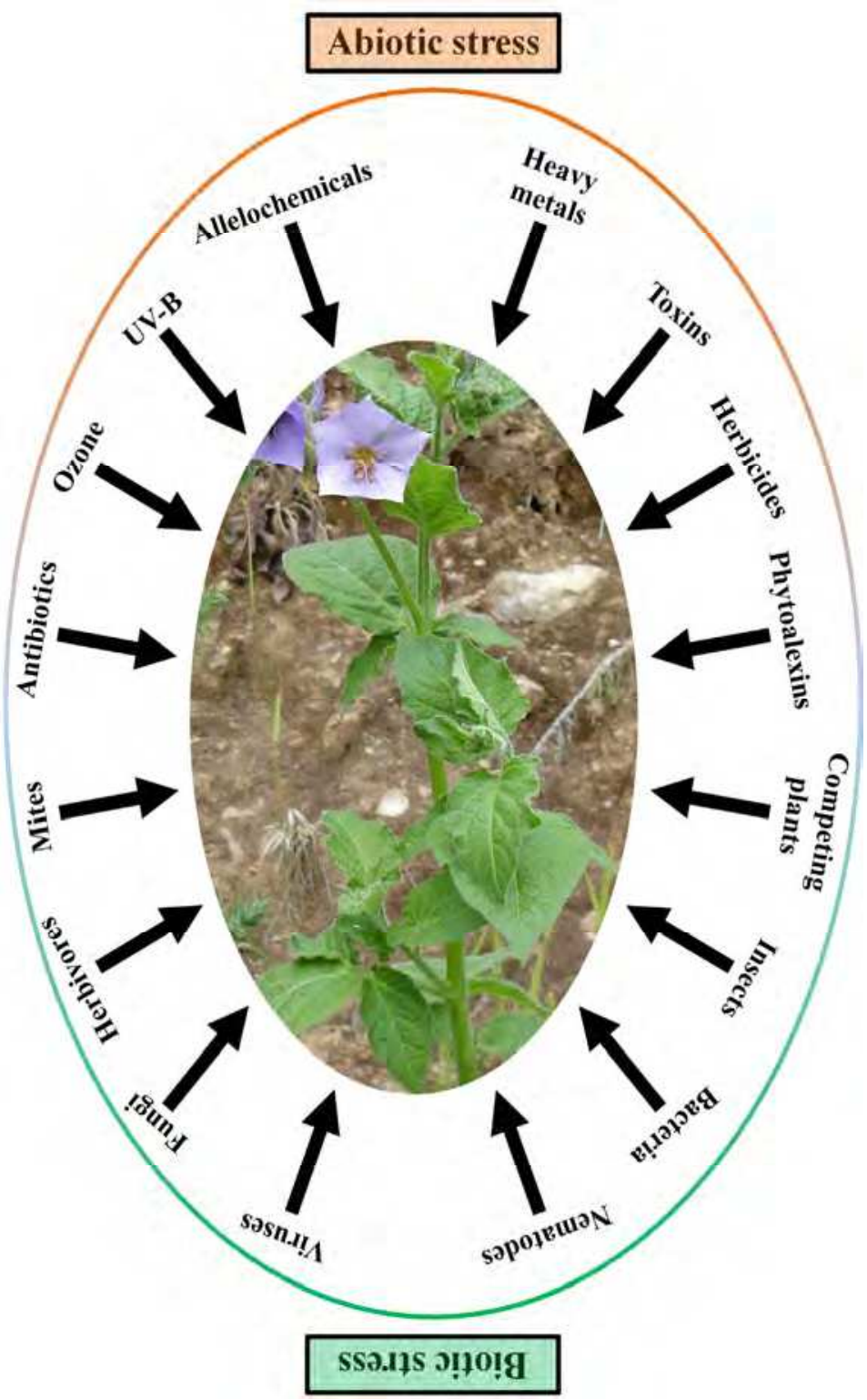

Fig. 1. Overview of selective environmental stress factors which could threaten plants. Biotic and abiotic environmental selective factors are considered. 


\section{The reactive oxygen species}

All plants use the dioxygen as a source of energy for their development. However, this aerobic process could lead to the production of reactive oxygen species which are diversified chemically reactive molecules containing oxygen. Reactive oxygen species are a natural byproduct of the metabolism and play important roles in homeostasis and cell signaling. However, under environmental stress, their levels can increase dramatically which lead to disruptions and damages in cell compartments.

\subsection{Diversity and toxicity}

An uncompleted reduction of the dioxygen through cytochroms from the respiratory chain implies the production of reactive oxygen species as singlet oxygen $\left({ }^{1} \mathrm{O}_{2}\right)$ and superoxide radical $\left(\mathrm{O}_{2} \cdot{ }^{-}\right)$which leads to the synthesis of hydroxyl radical $(\cdot \mathrm{OH})$, hydroperoxyl radical $\left(\cdot \mathrm{O}_{2} \mathrm{H}\right)$ and hydrogen peroxide $\left(\mathrm{H}_{2} \mathrm{O}_{2}\right)$ (Fig. 2). The radicals alkoxyl ( $\left.\mathrm{RO} \cdot{ }^{\bullet}\right)$ and peroxyl $\left(\mathrm{RO}_{2}{ }^{\circ}\right)$ are the consequence of the peroxidation of membrane phospholipids (or lipoperoxidation) by the previous reactive oxygen species (Fig. 3) (Edreva, 2005; Lagadic et al., 1997; Li et al., 1994; Thompson et al., 1987).

At the same time, the photosynthetic electron transport chains could product high concentrations of reactive oxygen species. Indeed, the electrons tetravalently reduce the intracellular oxygen to water. But, some electrons could leak from many sites along the electron transport chain, resulting in a univalent reduction of dioxygen to form the extremely reactive superoxide radical which can dismutate to form hydrogen peroxide (Alscher et al., 2002). This last reaction is spontaneous or catalyzed by one of the superoxide dismutases (Fig. 2) depending on the cell compartment where the reaction occurs: manganese-superoxide dismutase (mitochondria, peroxisome), iron-superoxide dismutase (chloroplast) or copper/zinc-superoxide dismutase (chloroplast, cytosol) (Fornazier et al., 2002; Gill \& Tuteja, 2010; Pereira et al., 2002).

The hydrogen peroxide is not a free radical due to all its matched electrons. However, it has a strong toxicity potential: it has a long lifespan and a high diffusibility far from its synthesis site. Indeed, it could pass through biological membranes via aquaporins as it presents a chemical structure close to water (Bienert et al., 2006, 2007; Parent et al., 2008). The concentration of this oxidative compound is regulated by antioxidant enzymes like the ascorbate peroxidase, the catalase or the glutathione peroxidase (Fig. 2). These proteins use the nicotinamide adenine dinucleotide phosphate (NADPH) produced during the photosynthesis in chloroplasts for their functioning (Fig. 2). However, the reactive oxygen species could disrupt the photosynthetic electron transport chains in thylakoid membranes and some electrons are deflected. Without a normal synthesis of NADPH, plants use a cytosolic secondary catabolism pathway to produce it, the pentose phosphate pathway (Fig. 4) (Delmail, 2011; Kruger \& von Schaewen, 2003). The hydrogen peroxide could be also produced through the bivalent reduction of the oxygen in presence of oxidases like the peroxisomal glycolate oxidase or the amine oxidase (Parent et al., 2008). The toxicity of hydrogen peroxide is also linked to its implication in the synthesis of the hydroxyl and hydroperoxyl radicals through the Haber-Weiss and Fenton reactions (Fig. 2). Like their reactive-oxygen-species mother, these short-lifespan radicals are very diffusive through biological membranes and they could disturb and affect all organites and cell compartments. They are also mainly implied in the lipoperoxidation (Fig. 3) (Edreva, 2005 ; Lagadic et al., 
1997). The produced fatty-acid radical then reacts with molecular oxygen, thereby creating a peroxyl fatty acid radical. This last one reacts with another phospholipid, producing a new radical and a lipid peroxide, or a cyclic peroxide if it reacts with itself. This cycle continues as a chain reaction mechanism (Schaich, 2005). This process ends up when two radicals react and produce a non-radical compound. It happens when the concentrations of radicals is high enough. Living organisms have evolved different molecules that speed up termination by catching the reactive oxygen species (Paramesha et al., 2011). Among such antioxidants, the most important are the scavengers mainly constituted with a-tocopherol (or vitamin E) and carotenoids ( $\beta$-caroten, xantophylls) (Figs. 2 and 3) (Delmail et al., 2011c, 2011d).

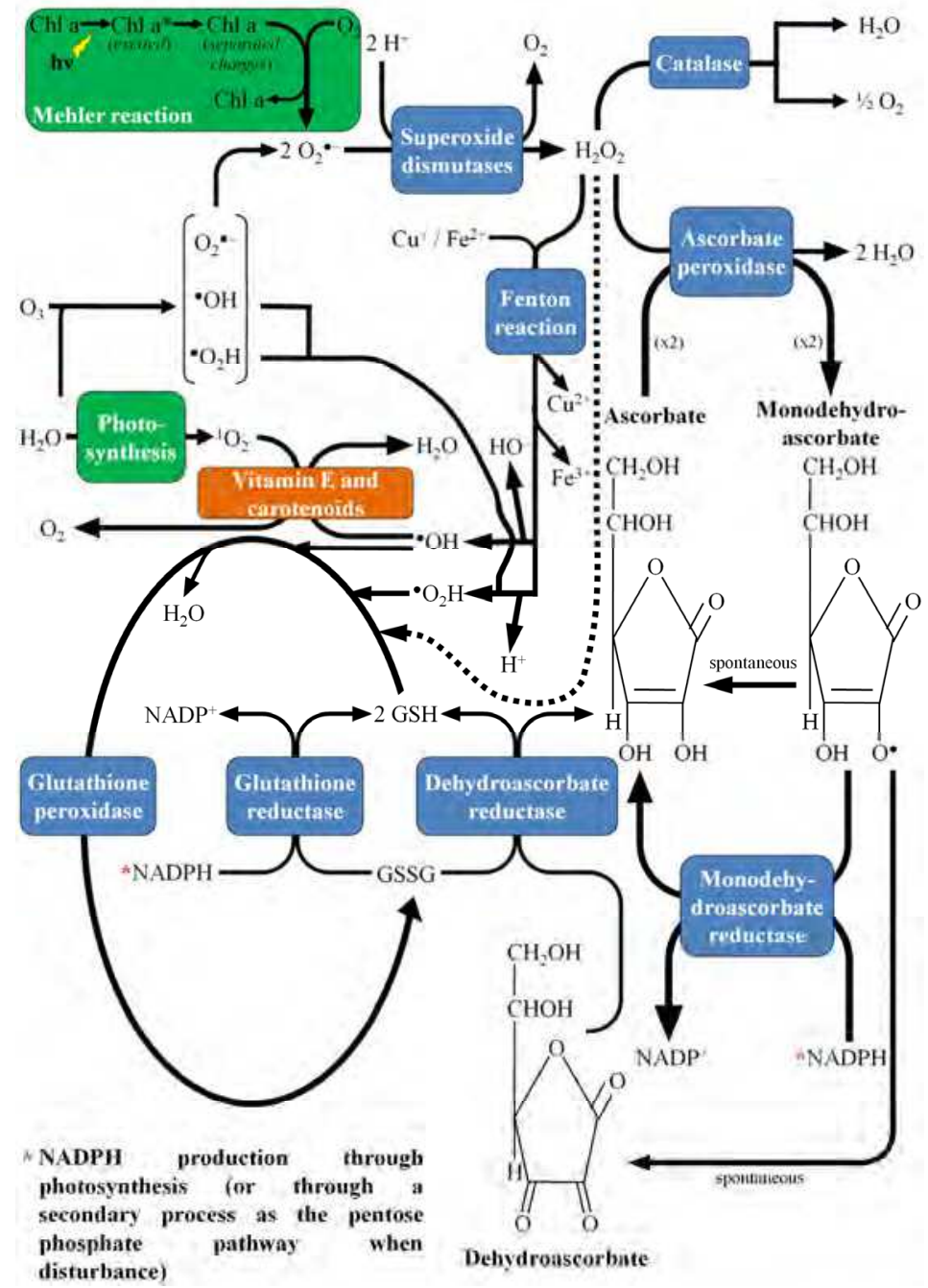

Fig. 2. Main plant antioxidant pathways including enzymes and scavengers (based on Delmail (2011)). 


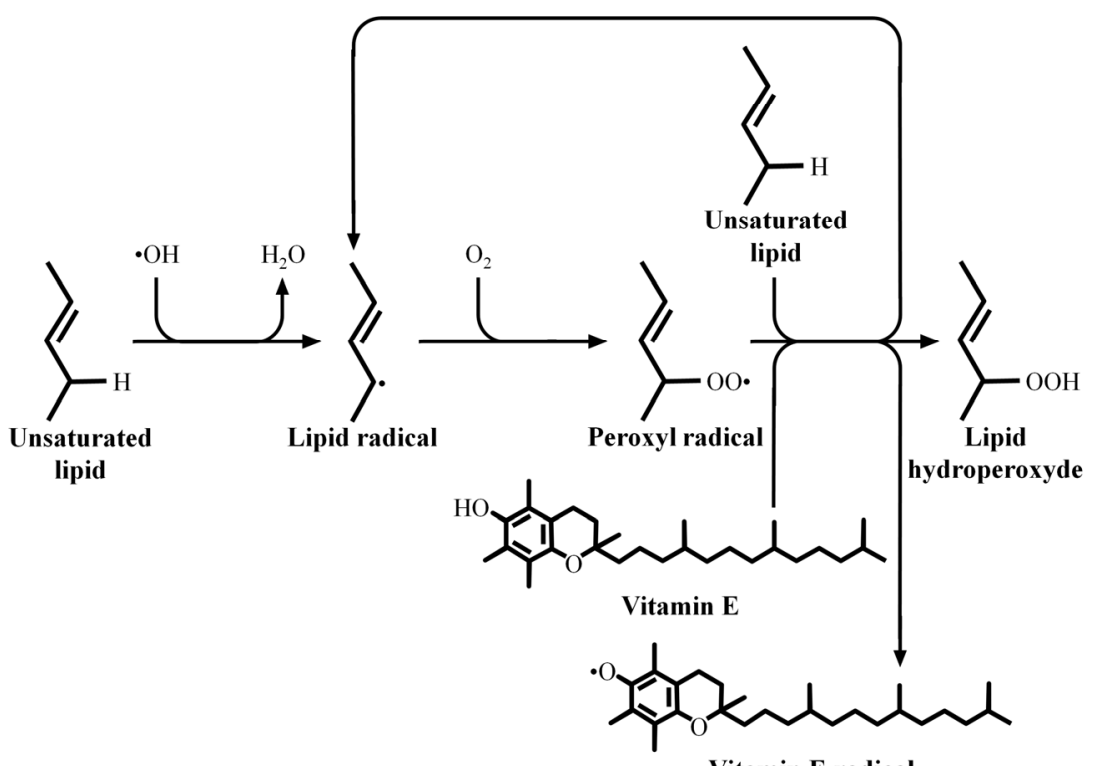

Vitamin E radical

Fig. 3. Mechanisms of lipid peroxidation in biological membranes. The produced peroxyl radicals could react either with another lipid to supply the lipoperoxidative chain reaction mechanism or with a scavenger like the vitamin $\mathrm{E}$ which disrupts and stops the oxidative process.

\section{Glucose-6-phosphate}
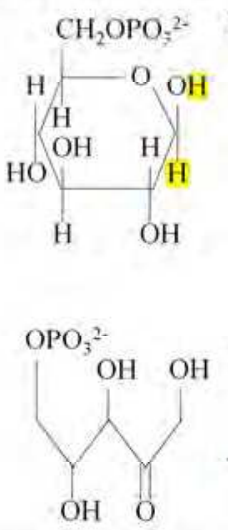

Ribulose-5-phosphate

\section{6-phosphogluconolactone}

NADP* NADPH. $\mathrm{H}^{*} \quad \mathrm{CH}_{2} \mathrm{OPO}_{3}^{2-}$
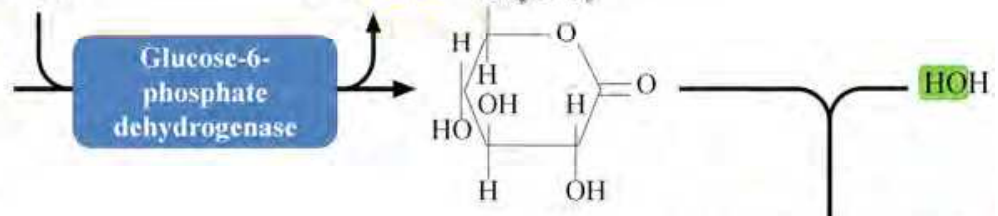

6-Phosphoglucono-

lactonase

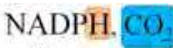

\section{6-phosphogluconate}

\section{dehydrugenase}

$\mathrm{NADP}^{+} \quad \mathrm{OPO}_{3}^{2-}$

\section{$\mathrm{OH}$}

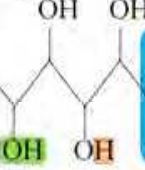

$\mathrm{H}^{+}$

6-phosphogluconate

Fig. 4. Reactions of NADPH synthesis through the oxidative phase of the pentose phosphate pathway of plants (based on Delmail (2011)). 
Considering all these elements, the reactive oxygen species are considered as phytotoxic compounds. However, it is currently admitted that their synthesis, in relation to the respiratory and photosynthetic metabolisms, plays an essential role in the life and the death of plant cells. Indeed, they could play an alternative role and act as cell signalization molecules to establish some defense mechanisms towards a xenobiotic stress (Parent et al., 2008).

\subsection{Role in cell death and protection of living parts}

The reactive oxygen species are known for their importance in the plant responses towards environmental disturbances. Several symptoms like necrosis (Fig. 5), are the consequences of a high oxidative-compound accumulation and a disturbance of cell homeostasis.

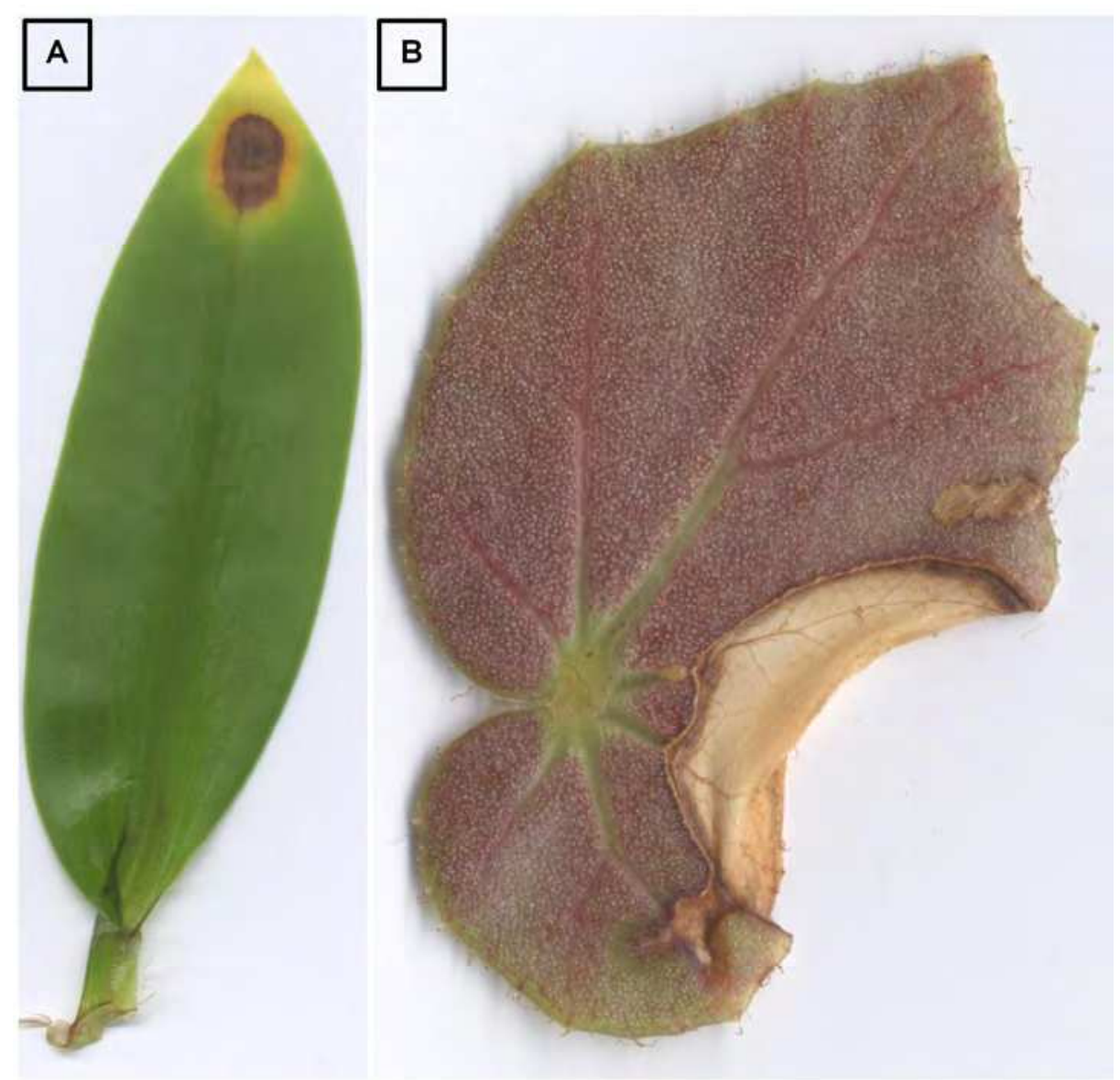

Fig. 5. Leaf of Tradescantia sp. (A) and Begonia sp. (B) with symptoms of photosyntheticpigment oxidation and cell necrosis. 
This phenomenon is due to an oxidation of photosynthetic pigments in chlorophyllian organs and to the death of isolated cells or groups of cells in many plant tissues. Despite that reactive oxygen species could be produced in normal conditions, the increase of their concentrations in plants is often linked to xenobiotics (Parent et al., 2008). For example, an increase of hydrogen peroxide is observed in peroxisomes of the aquatic macrophyte Myriophyllum alterniflorum after an exposition to cadmium chloride from 0.5 to $10 \mu \mathrm{g} . \mathrm{l}^{-1}$ (Delmail, 2011). Moreover, the oxidative stress generated by this reactive oxygen species is all the more important during the 2-3 weeks of contamination that the heavy-metal concentration is high. Indeed, the activity of the catalase is higher during a longer period when the toxicity increases (Delmail, 2011).

It could be also noted that many of the symptoms due to the xenobiotics stress are amplified by the presence of reactive oxygen species. In the same species, when $M$. alterniflorum is contaminated with copper sulphate from 5 to $100 \mu \mathrm{g} . \mathrm{l}^{-1}$, an increase of the catalase activity is observed up to $25 \mu \mathrm{g} . \mathrm{l}^{-1}$ to reduce this reactive oxygen species into water (Delmail, 2011). Beyond this toxicity limit, the intensity of the enzymatic activity decreases due to a disruption of the antioxidant pathways. The catalase activity of plants is known to be sensitive to oxidative stress when a lack of iron (or sometimes magnesium) occurs (Esfandiari et al., 2010; Iturbe-Ormaetxe et al., 1995; Tewari et al., 2005) as this protein needs an iron ion in its constitutive heme (Arménia Carrondo et al., 2007). A competitive effect between the excess of copper and the other elements during the adsorption/absorption (Bernal et al., 2007) could lead to a disturbance during the catalase synthesis (Delmail, 2011).

Despite of their extremely toxic nature, the reactive oxygen species are also implied in cascades of signalization which induce the expression and the regulation of many genes. These genes could be involved in the defense mechanisms, like the phytochelatine synthase which allows the synthesis of heavy-metal binding peptides, the phytochelatins. These compounds play important roles in the detoxification of toxic heavy metals and the regulation of intracellular concentrations of essential metals in plants (Hirata et al., 2005). The primary structure of phytochelatins generally have the form ( $\gamma$-glutamate-cysteine $)_{n}{ }^{-}$ glycine and these peptides could form complexes with heavy metals such as cadmium (Fig. 6), copper, zinc, mercury, silver and arsenic, which are stored as inactive in the cell vacuoles. The expression of phytochelatin synthase in Populus tremula $x$ tremuloides cv. Etrepole transgenic lines expressing the wheat phytochelatin synthase TaPCS1 is stimulated by the presence of heavy metal and this protein aimed at increasing metal tolerance and metal accumulation through overproduction of phytochelatins (Couselo et al., 2010).

The reactive oxygen species are also implied in the apoptosis (or programmed cell death) of plants as regulating agents (Dat et al., 2003; Van Breusegem et al., 2006). This event occurs during all the life of organisms and selected cells or organs are eliminated from the living parts through senescence or abscission to maintain the optimal development of the organisms. During the growth, the apoptosis is involved in several phenomena like the triggering of the aleurone cells to release amylase during the germination of caryopsis, the differentiation of xylem and phloem elements, the development of the root cap and the abscission of leaves (Parent et al., 2008). But plants may use this apoptosis to adapt and to resist towards environmental stress like pathogens. For example, the infection of Nicotiana obtusifolia by the downy mildew pathogen Peronospora tabacina resulted in a compatible interaction, in which P. tabacina penetrated and colonized host leaf tissue (Heist et al., 2004). 
This interaction becomes incompatible several days later and it leads to an oxidative burst, with the appearance of necrotic lesions due to reactive oxygen species, which isolates the pathogen from the living parts. This conducts to the inhibition of the pathogen growth. These necrotic lesions are due to hypersensitive cell death in the host and the resistance phenotype was due to the action of a gene known to confer a hypersensitive response, Rpt1 (Heist et al., 2004).

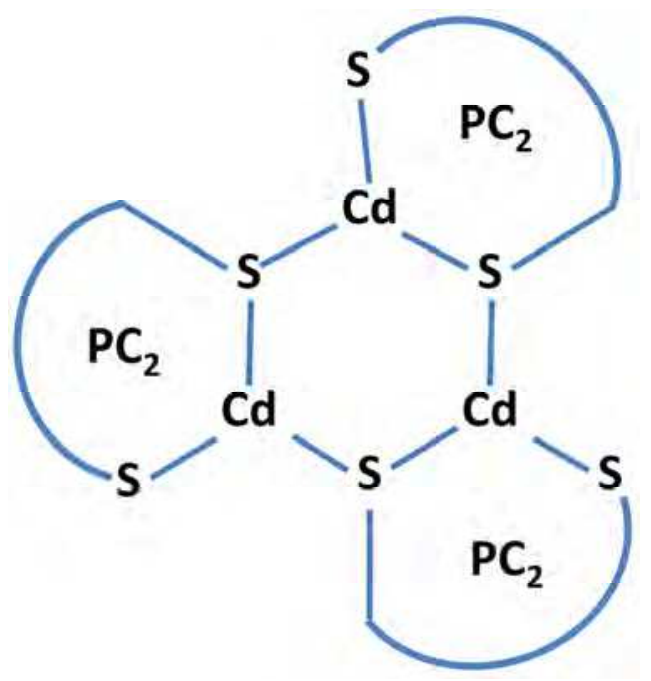

Fig. 6. Schematic structure and organization of phytochelatins implied in the sequestration mechanism of cadmium (Cd) through thiol function (SH) and constituted each of $2 \gamma$ glutamylcysteine parts $\left(\mathrm{PC}_{2}\right)$ (based on Delmail (2011)).

\section{Senescence and abscission}

Leaf senescence is a highly regulated process particularly well studied in crop plants and Arabidopsis (Balazadeh et al., 2008). Nowadays it is conspicuous that environmental stresses can induce precocious senescence (Balazadeh et al., 2008) as hypothesized since 1997 by Ouzounidou et al. during the observation of the effect of cadmium on wheat; but the effect of heavy metal ions on this phenomenon is still poorly documented. However, it was demonstrated that protein functioning as metal chelator like metallothionein may be needed to protect normal cell functions from the toxic effects of metal ions released during senescence. In that sense, metallothioneins may be involved in chaperoning released metal ions to avoid metal toxicity or metal induced-oxidative stress in plant cell during the senescence process. Guo et al. (2003) indicated that all the Arabidopsis metallothionein genes expressed in vegetative tissues were upregulated in senescing leaves thus protecting cells from metal ions toxicity during senescence. A similar observation of the implication of some metallothioneins in leaf senescence and in heavy metal stress was done in barley by Heise et al. (2007).

Another important molecule involved during senescence is the yellow stripe-like transporter family (YSL). Curie et al. (2009) indicated that five out the eight Arabidopsis YSL genes are most strongly expressed in senescent leaves. Indeed, the expression of AtYSL1 and 
AtYSL3 is increased during senescence and although the leave of the double ysl1ysl3 mutant loses only $10 \%$ of copper content between the 4 th and the 5 th week of growth, the wild type Arabidopsis loses almost 60\%. More recently Xiao \& Chye (2011) evidenced new roles for acyl-CoA-binding proteins (ACPBs). Indeed, in Arabidopsis the expression of AtACPB3 was upregulated during senescence and AtACPB3-KOs Arabidopsis displayed delayed leaf senescence whereas AtACPB3-overexpressors Arabidopsis present an accelerated leaf senescence phenotype. On the other hand these authors indicated that Arabidopsis AtACPB2overexpressors were more tolerant to cadmium in the growing media.

Among the different mechanisms adopted by plants to cope with metallic stress (phenological escape, exclusion, amelioration and tolerance), the amelioration one implies that the ion must be removed from the circulation or tolerated within the cytoplasm. These amelioration processes include excretion either actively - through glands on aerial part or by roots - or passively by accumulation in old leaves followed by abscission (Adams \& Lamoureux, 2005). The simplest form of excretion is the loss of an organ which has accumulated the toxic compounds. This is generally true for the old leaves that present higher content of toxics than the young leaves and buds. For example, Yasar et al. (2006) noticed that the toxic sodium ion was stored in old leaves of the salt-tolerant Gevas Sirik 57 (GS57) green bean genotype acting as a protection mechanism from the detrimental effect of sodium for young leaves. In the same way, Szarek-Lukaszewska et al. (2004) indicated that an Armeria maritima population from metalliferous soil directed to the oldest leaves a part of the metal transported to aboveground plant organs. For these authors the ability to accumulate metals in withering leaves characterizes plants growing under strong environmental pressure from metal contamination. Detoxification mechanism by leaf fall was a strategy previously suggested by Dahmani-Mueller et al. (2000) in Armeria maritima spp. halleri where metal content (cadmium, copper, lead and zinc) in ageing leaves (brown leaves) were 3-8 times higher than in green leaves. A similar observation was done by Monni et al. (2001) on a shrub (Empetrum nigrum) which accumulates metals (cadmium, copper, iron, lead, nickel and zinc) in older tissues, mainly leaves and bark, by both accumulation and surface contamination. For tree species, Pahalawattaarachchi et al. (2009) shown that in Rhizophora mucronata chromium, cadmium and lead were accumulated in leaves before abscission and thus eliminated. A major disadvantage of the excretion strategy for plant is that they are stationary so the excreted substance will remain in the root zone and may eventually lead to a build-up of the xenobiotic (Adams \& Lamoureux, 2005).

Only few data were available on aquatic macrophyte, a case where this major disadvantage did not apply. For example in Spirodela polyrrhiza, the excess of iron and copper induces plant necrosis, colony disintegration and root abscission (Xing et al., 2010). It should be noted that in another aquatic macrophyte, Lemna minor, the frond abscission could be used to test water toxicity induced by metal and other compounds (Henke et al., 2011). Our previous data (Delmail et al., 2011d) suggest that as in terrestrial plants a similar excretion strategy could occur in aquatic plants. Indeed, Myriophyllum alterniflorum old leaves are much more affected by heavy-metal pollution than younger ones. Previous study of Jana \& Chouduri (1982) on three submerged aquatic macrophytes (Potamogeton pectinatus, Vallisneria spiralis and Hydrilla verticillata) demonstrated that all the heavy metals tested (cadmium, copper, lead and mercury) hastened the senescence process. These authors evidenced the role of the plant growth regulator kinetin in the reduction of the senescence induced by heavy metals. 
The role of plant growth regulator in senescence and in heavy-metal resistance is quite complex but cytokinins for their senescence delaying action (for a review see Werner \& Schmulling, 2009) and brassinosteroids for their role in responses to various environmental stress (for a review see Bajguz \& Hayat, 2009) appeared as major candidates for further studies to understand the heavy-metal induced senescence processes. Indeed, Arora et al. (2010) demonstrated that the brassinosteroid 24-epibrassinolide present stress-ameliorative properties in Brassica juncea plant during chromium stress as an improved growth and antioxidant enzymes activities. Similar conclusion was highlighted by Anuradha \& Rao (2007) on Raphanus sativus plant were brassinosteroids supplementation alleviated the toxic effect of cadmium. More recently, Bajguz (2011) noted on Chlorella vulgaris that the brassinosteroid application to the culture prevents chlorophyll, sugar and protein loss and increases phytochelatin synthesis during heavy metal stress (cadmium, copper and lead). These reactions call to mind the delayed senescence process observed previously in aquatic macrophytes when treated with cytokinins during a heavy-metal stress. In the same way, brassinosteroid treatment improves sunflower (genotype 2603) and turnip (var. rave du Limousin) resistance to cadmium stress in terms of photosynthesis activities (Figs. 7 and 8, Delmail et al. unpublished data).

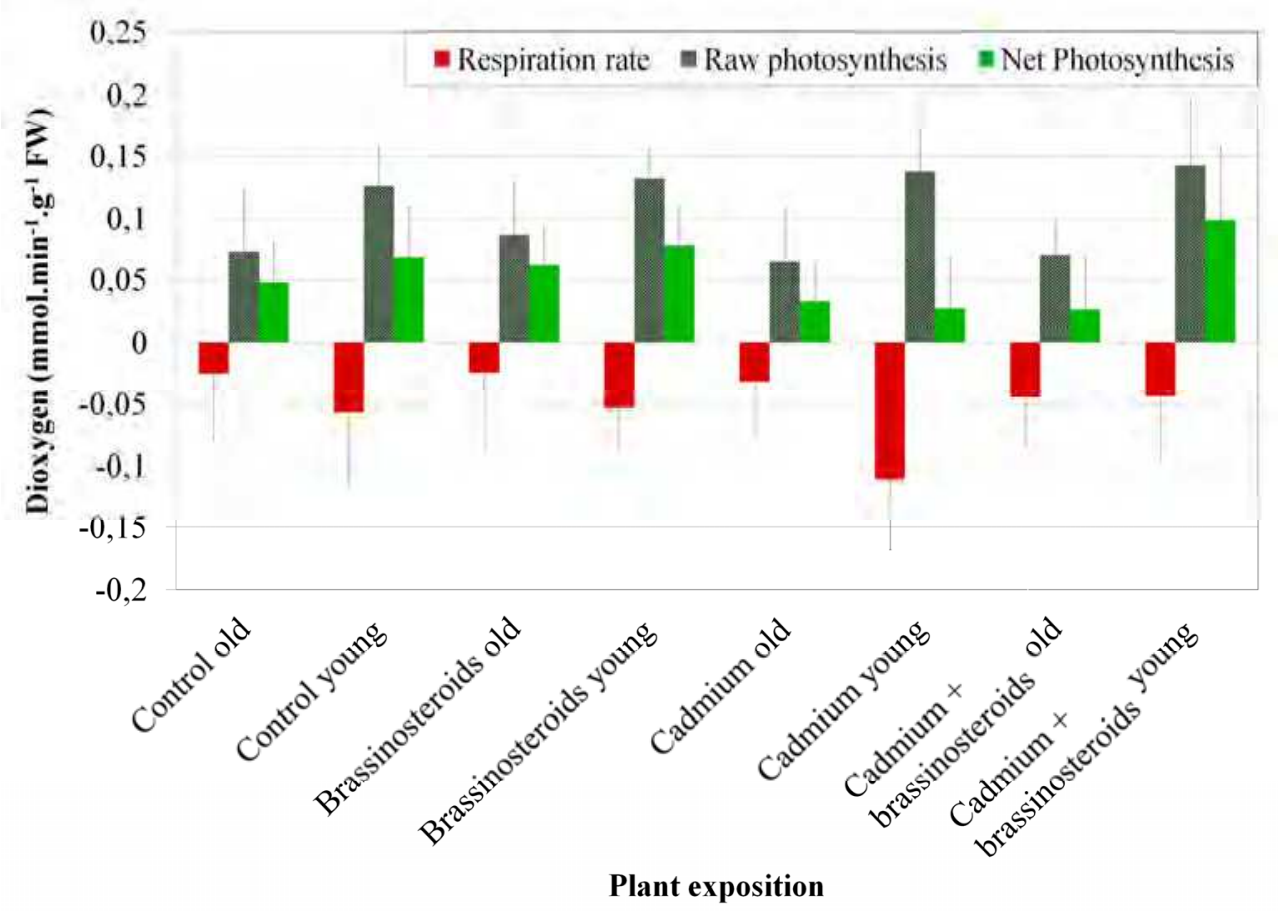

Fig. 7. Photosynthetic activities and respiration rate of one-month old sunflower specimens after $48 \mathrm{~h}$ of cadmium exposure $(1 \mathrm{mM})$ combined or not with $3 \mu \mathrm{M}$ 24-epibrassinolid (Delmail et al. unpublished data). FW, fresh weight. 


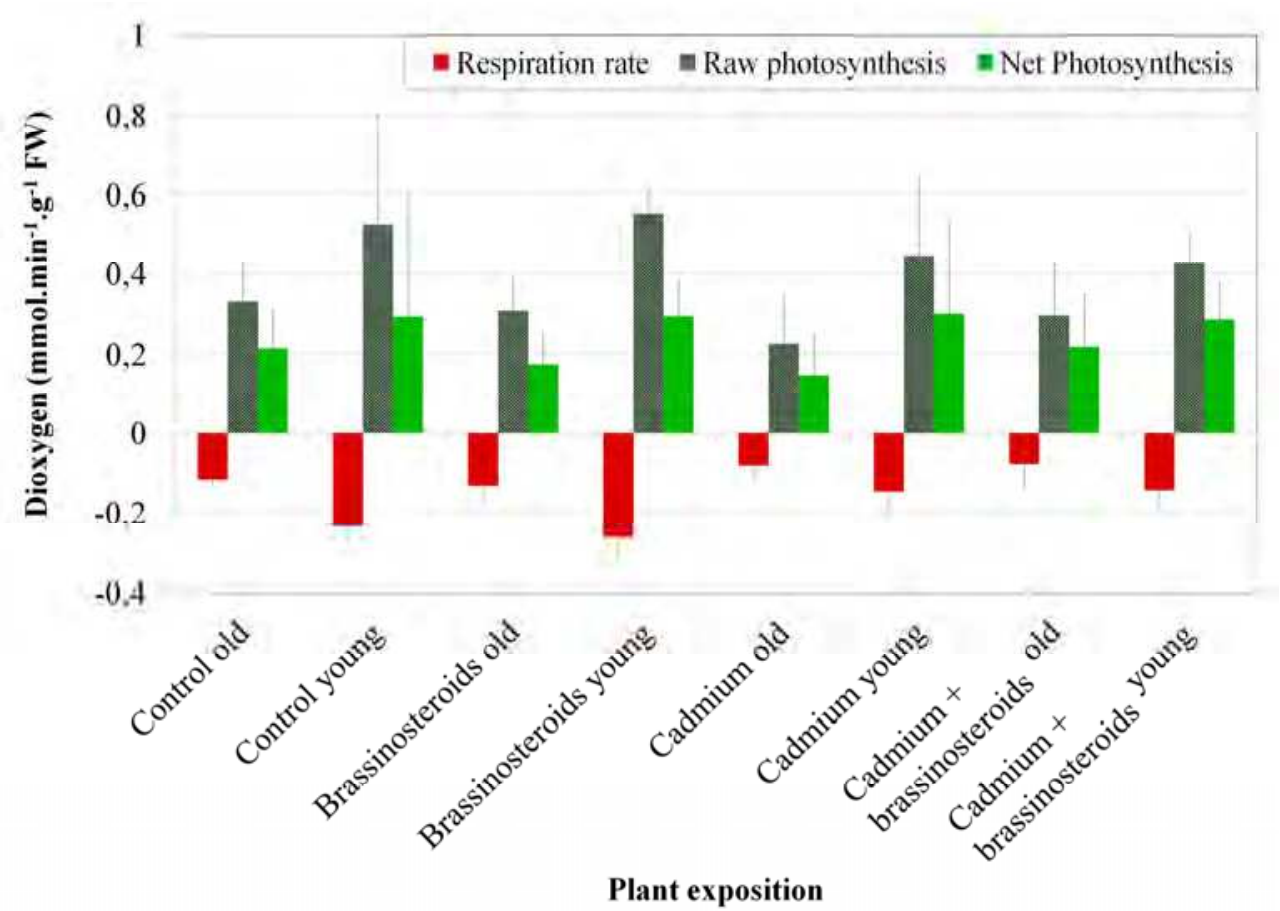

Fig. 8. Photosynthetic activities and respiration rate of one-month old turnip specimens after $72 \mathrm{~h}$ of cadmium exposure $(1 \mathrm{mM})$ combined or not with $3 \mu \mathrm{M}$ 24-epibrassinolid (Delmail et al. unpublished data). FW, fresh weight.

Moreover, the effect of brassinosteroids on antioxidant enzymatic activities during cadmium stress could be similar in young and old leaves as shown in Fig. 9 for a decrease in catalase activity of sunflower plants treated with phytohormons during a heavy-metal stress. On the other hand, as demonstrated in turnip (Fig. 10) a differential effect between old and young leaves could appear with an increase in superoxide-dismutase activity in young leaves and a decrease in old leaves (Delmail et al. unpublished data). In these two plants, brassinosteroid application clearly has a protective effect on the raw photosynthesis activity, probably indicating a delayed heavy-metal senescence. These protective actions probably also occur on the enzymatic antioxidant system even if the complexity of the involved cascade reactions lead to a more unclear landscape inducing pattern variations between studied enzymes, age of plant parts and plant species. It appears clearly that much more studies are needed to understand the complex interwoven relationship existing between plant physiology under heavy-metal stress, senescence and plant growth regulators.

Concerning the organic xenobiotics effect on plant senescence even much less data are available. For example, Cape et al. (2003) noted that in Lotus corniculatus exposes to a mixture of six volatile organic compounds (acetone, acetonitrile, dichloromethane, ethanol, methyl t-butyl ether and toluene), a premature senescence occurs but in this case a premature senescence refers to advanced timing of seed pot production. Another example 
concerns the die-back symptom of Phragmites communis where the premature senescence of shoot appears to result at least in part from phytotoxin action (acetic, propionic, n- and isobutyric and n-caproic acids and sulphide) (Armstrong \& Armstrong, 2001).

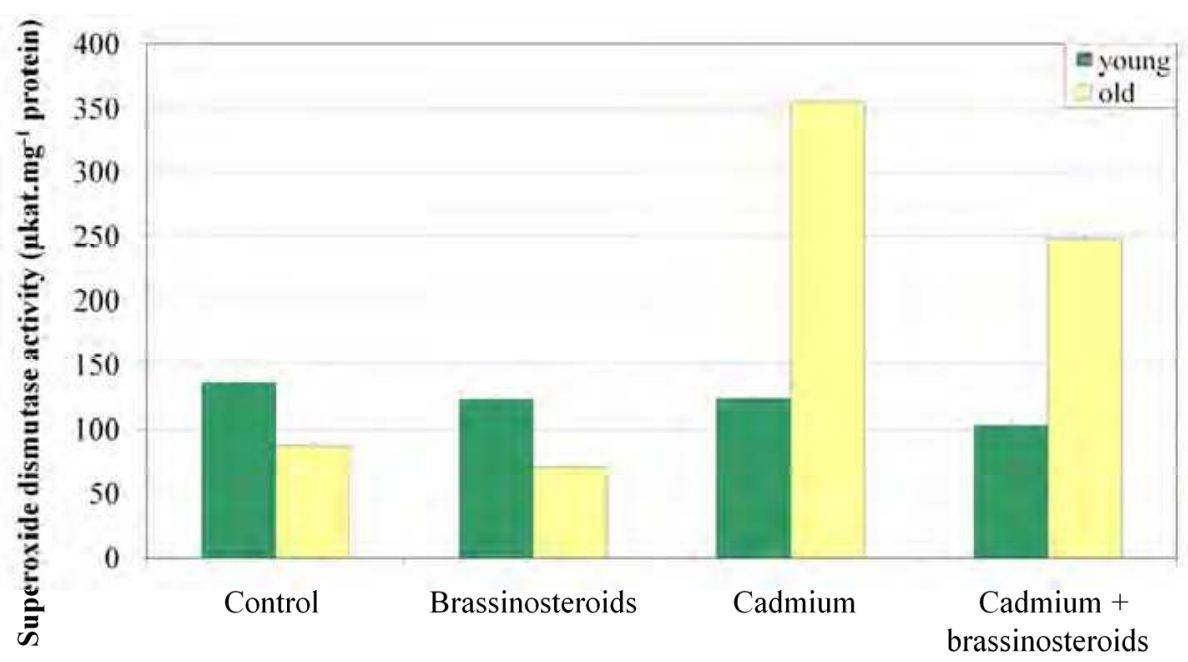

Plant exposition

Fig. 9. Superoxide dismutase activity of one-month old sunflower specimens after $48 \mathrm{~h}$ of cadmium exposure $(1 \mathrm{mM})$ combined or not with $3 \mu \mathrm{M}$ 24-epibrassinolid (Delmail et al. unpublished data).

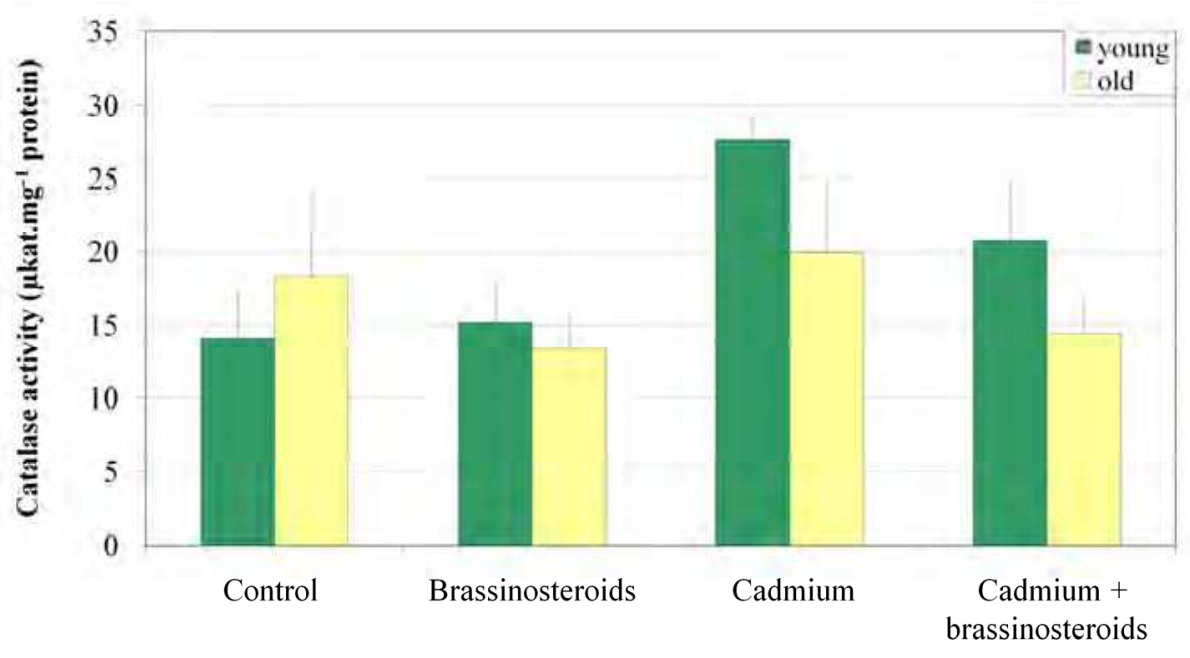

Plant exposition

Fig. 10. Catalase activity of one-month old turnip specimens after $72 \mathrm{~h}$ of cadmium exposure (1 mM) combined or not with $3 \mu \mathrm{M}$ 24-epibrassinolid (Delmail et al. unpublished data). 


\section{Conclusion}

Senescence implies a succession of physiological events integrated with developmental program which lead to the loss of several organs from the plant. This biological process constitutes an integral part of the normal plant developmental cycle which can be observed at different organization levels (cell, tissue and organ). The senescence is the final event in the life of many plant tissues and it is a highly regulated process that involves structural, biochemical and molecular changes.

Organic and inorganic xenobiotics could hasten the senescence processes and they may lead to a premature death of the plants. At the opposite, the senescence occurring in the plant organs could isolate the stressors and/or eliminate the toxics from the living parts through induced abscission.

\section{Acknowledgment}

This research was partially supported by the University of Limoges, the GRESE (Research Group on Water, Soil and the Environment) EA 4330, and the Conseil Régional du Limousin.

\section{References}

Adams, P.W., Lamoureux, S. (2005). Resistance to toxicity, In: A literature review of the use of native Northern plants for the re-vegetation of Arctic mine tailings and mine waste, 31.08.2011, Available from

http://www.enr.gov.nt.ca/_live/documents/content/WKSS_Northern_Plants_Re -vegetation-2005.pdf

Alscher, R.G., Erturk, N., Heath, L.S. (2002). Role of superoxide dismutases (SODs) in controlling oxidative stress in plants. Journal of Experimental Botany, Vol.53, No.372, (May 2002), pp. 1331-1341, ISSN 0022-0957

Anuradha, A., Rao, S.S.R. (2007). The effect of brassinosteroids on radish (Raphanus sativus L.) seedlings growing under cadmium stress. Plant, Soil and Environment, Vol.53, No.11, (November 2007), pp. 465-472, ISSN 1214-1178

Arménia Carrondo, M., Bento, I., Matias, P.M., Lindley, P.F. (2007). Crystallographic evidence for dioxygen interactions with iron proteins. Journal of Biological Inorganic Chemistry, Vol.12,No.4, (May 2007), pp. 429-442, ISSN 0949-8257

Armstrong, J., Armstrong, W. (2001). An overview of the effects of phytotoxins on Phragmites australis in relation to die-back. Aquatic Botany, Vol.69, No.2-4, (April 2001), pp. 251-268, ISSN 0304-3770

Arora, P., Bhardwaj, R., Kanwar, M.K. (2010). 24-epibrassinolide regulated diminution of Cr metal toxicity in Brassica juncea L. plants. Brazilian Journal of Plant Physiology, Vol.22, No.3, (September 2010), pp. 159-165, ISSN 1677-0420

Bajguz, A. (2011). Suppression of Chlorella vulgaris growth by cadmium, lead, and copper stress and its restoration by endogenous brassinolide. Archives of Environmental Contamination and Toxicology, Vol.60, No.3, (April 2011), pp. 406-416, ISSN 00904341 
Bajguz, A., Hayat, S. (2009). Effects of brassinosteroids on the plant responses to environmental stresses. Plant Physiology and Biochemistry, Vol.47, No.1, (January 2009), pp. 1-8, ISSN 0981-9428

Balazadeh, S., Riaño-Pachón, D.M., Mueller-Roeber, B. (2008). Transcription factors regulating leaf senescence in Arabidopsis thaliana. Plant Biology, Vol.10, No.SUPPL.1, (September 2008), pp. 63-75, ISSN, 1435-8603

Bernal, M., Cases, R., Picorel, R., Yruela, I. (2007). Foliar and root Cu supply affect differently $\mathrm{Fe}$-and Zn-uptake and photosynthetic activity in soybean plants. Environmental and Experimental Botany, Vol.60, No., (2), pp. 145-150, ISSN 0098-8472

Bienert, G.P., Schjoerring, J.K., Jahn, T.P. (2006). Membrane transport of hydrogen peroxide. Biochimica et Biophysica Acta - Biomembranes, Vol.1758, No.8, (August 2006), pp. 9941003, ISSN 0005-2736

Bienert, G.P., Møller, A.L.B., Kristiansen, K.A., Schulz, A., Møller, I.M., Schjoerring, J.K., Jahn, T.P. (2007). Specific aquaporins facilitate the diffusion of hydrogen peroxide across membranes. The Journal of Biological Chemistry, Vol.282, No.2, (January 2007), pp. 1183-1192, ISSN 0021-9258

Cape, J.N., Leith, I.D., Binnie, J., Content, J., Donkin, M., Skewes, M., Price, D.N., Brown, A.R., Sharpe, A.D. (2003). Effects of VOCs on herbaceous plants in an open-top chamber experiment. Environmental Pollution, Vol.124, No.2, (July 2003), pp. 341353, ISSN 0269-7491

Couselo, J.L., Navarro-Avĩnó, J., Ballester, A. (2010). Expression of the phytochelatin synthase TaPCS1 in transgenic aspen, insight into the problems and qualities in phytoremediation of $\mathrm{Pb}$. International Journal of Phytoremediation, Vol.12, No.4, (April 2010), pp. 358-370, ISSN 1522-6514

Curie, C., Cassin, G., Couch, D., Divol, F., Higuchi, K. , Le Jean, M. , Misson, J. , Schikora, A. , Czernic, P., Mari, S. (2009). Metal movement within the plant: Contribution of nicotianamine and yellow stripe 1-like transporters. Annals of Botany, Vol.103, No.1, (January 2009), pp. 1-11, ISSN 0305-7364

Dahmani-Muller, H., Van Oort, F., Gélie, B., Balabane, M. (2000). Strategies of heavy metal uptake by three plant species growing near a metal smelter. Environmental Pollution, Vol.109, No.2, (August 2000), pp. 231-238, ISSN 0269-7491

Dat, J.F., Pellinen, R., Beeckman, T., Van De Cotte, B., Langebartels, C., Kangasjarvi, J., Inze, D., Van Breusegem, F. (2003). Changes in hydrogen peroxide homeostasis trigger an active cell death process in tobacco. The Plant Journal, Vol.33, No.4, (February 2003), pp. 621-632, ISSN 0960-7412

Delmail, D. (2007). Ecologie florale bretonne. La Garance Voyageuse, Vol.79, No.1, (September 2007), pp. 14-17, ISSN 0988-3444

Delmail, D. (2011). Contribution de Myriophyllum alterniflorum et de son périphyton à la biosurveillance de la qualité des eaux face aux métaux lourds, Université de Limoges, Limoges, France

Delmail, D., Labrousse, P., Buzier, R., Botineau, M. (2009). Importance of Myriophyllum alterniflorum D.C., an aquatic macrophyte, in biomonitoring of trace metal pollution in running freshwater, Proceedings of EMEC10 10th European Meeting on Environmental Chemistry, pp. 66, Limoges, France, December 2-5, 2009

Delmail, D., Labrousse, P., Hourdin, P., Botineau, M. (2010). Use of Myriophyllum alterniflorum (Haloragaceae) for restoration of heavy-metal-polluted freshwater 
environments: preliminary results, Proceedings of 7th SER European Conference on Ecological restoration and sustainable development, pp. 103, Avignon, France, August 23-27, 2010

Delmail, D., Labrousse, P., Crassous, P., Hourdin, P., Guri, M., Botineau, M. (2011a). Simulating the dynamics of epiphytic diatom metacommunity in stream environments contaminated with heavy metals, Proceedings of ECEM 2011 7th European Conference on Ecological hierarchy from the genes to the biosphere, pp. 112, Riva del Garda, Italy, May 30-June 2, 2011

Delmail, D., Labrousse, P., Hourdin, P., Botineau, M. (2011b). Evidence of copper impact on freshwater environments using Myriophyllum alterniflorum: restoration, biomonitoring and management, Proceedings of IAVS 2011 54th International Symposium on Vegetation in and around water: patterns, processes and threats, pp. 157, ISBN 978-2-9539515-1-6, Lyon, France, June 20-24, 2011

Delmail, D., Labrousse, P., Hourdin, P., Larcher, L., Moesch, C., Botineau, M. (2011c). Differential responses of Myriophyllum alterniflorum DC (Haloragaceae) organs to copper: physiological and developmental approaches. Hydrobiologia, Vol.664, No.1, (April 2011), pp. 95-105, ISSN 0018-8158

Delmail, D., Labrousse, P., Hourdin, P., Larcher, L., Moesch, C., Botineau, M. (2011d). Physiological, anatomical and phenotypical effects of a cadmium stress in differentaged chlorophyllian organs of Myriophyllum alterniflorum DC (Haloragaceae). Environmental and Experimental Botany, Vol.72, No.2, (September 2011), pp. 174-181, ISSN 0098-8472

Edreva, A. (2005). Generation and scavenging of reactive oxygen species in chloroplasts: a submolecular approach. Agriculture, Ecosystems and Environment, Vol.106, No.2-3, (April 2005), pp. 119-133, ISSN 0167-8809

Esfandiari, E., Shokrpour, M., Alavi-Kia, S. (2010). Effect of Mg deficiency on antioxydant enzymes activities and lipid peroxidation. Journal of Agricultal Science, Vol.2, No.3, (September 2010), pp. 131-136, ISSN 1916-9752

Fornazier, R.F., Ferreira, R.R., Vitória, A.P., Molina, S.M.G., Lea, P.J., Azevedo, R.A. (2002). Effects of cadmium on antioxidant enzyme activities in sugar cane. Biologia Plantarum, Vol.45, No.1, (January 2002), pp. 91-97, ISSN 0006-3134

Gill, S.S., Tuteja, N. (2010). Reactive oxygen species and antioxidant machinery in abiotic stress tolerance in crop plants. Plant Physiology and Biochemistry, Vol.48, No.12, (December 2010), pp. 909-930, ISSN 0981-9428

Guo, W.-J., Bundithya, W., Goldsbrough, P.B. (2003). Characterization of the Arabidopsis metallothionein gene family: Tissue-specific expression and induction during senescence and in response to copper. New Phytologist, Vol.159, No.2, (August 2003), pp. 369-381, ISSN 0028-646X

Heise, J., Krejci, S., Miersch, J., Krauss, G.-J., Humbeck, K. (2007). Gene expression of metallothioneins in barley during senescence and heavy metal treatment. Crop Science, Vol.47, No.3, (May 2007), pp. 1111-1118, ISSN 0011-183X

Heist, E.P., Zaitlin, D., Funnell, D.L., Nesmith, W.C., Schardl, C.L. (2004). Necrotic lesion resistance induced by Peronospora tabacina on leaves of Nicotiana obtusifolia. Phytopathology, Vol.94, No.11, (November 2004), pp. 1178-1188, ISSN 0031-949X 
Henke, R., Eberius, M., Appenroth, K.-J. (2011). Induction of frond abscission by metals and other toxic compounds in Lemna minor. Aquatic Toxicology, Vol.101, No.1, (January 2011), pp. 261-265, ISSN 0166-445X

Hinsinger, P., Schneider, A., Dufey J.E. (2005). Le sol : ressource en nutriments et biodisponibilité, In : Sols et Environnement, M.-C. Girard, C. Walter, J.-C. Rémy, J. Berthelin, J.-L. Morel (Eds.), 285-305, Dunod, ISBN 978-2-1005-1695-7, Paris, France

Hirata, K., Tsuji, N., Miyamoto, K. (2005). Biosynthetic regulation of phytochelatins, heavymetal-binding peptides. Journal of Bioscience and Bioengineering, Vol.100, No.6, (December 2005), pp. 593-599, ISSN 1389-1723

Iturbe-Ormaetxe, I., Moran, J.F., Arrese-Igor, C., Gogorcena, Y., Klucas, R.V., Becana, M. (1995). Activated oxygen and antioxidant defences in iron-deficient pea plants. Plant, Cell and Environment, Vol.18, No.4, (April 1995), pp. 421-429, ISSN 0140-7791

Jana, S., Choudhuri, M.A. (1982). Senescence in submerged aquatic angiosperms: Effects of heavy metals. New Phytologist, Vol.90, No.3, (), pp. 477-484, ISSN 0028-646X

Kabata-Pendias, A., Pendias, H. (2000). Trace elements in soils and plants, CRC Press, ISBN 978-0-8493-1575-6, Boca Raton, Florida, USA

Kruger, N.J., von Schaewen, A. (2003). The oxidative pentose phosphate pathway: structure and organisation. Current Opinion in Plant Biology, Vol.6, No.3, (June 2003), pp. 236246, ISSN 1369-5266

Lagadic, L. , Caquet, T., Amiard J.-C. (1997). Biomarqueurs en écotoxicologie : principes et définitions, In: Biomarqueurs en écotoxicologie, L. Lagadic, T. Caquet, J.C. Amiard, (Eds.), 1-10, Masson Press, ISBN 2-225-83053-3, Paris, France

Li, Y., Trush, M.A., Yager, J.D. (1994). DNA damage caused by reactive oxygen species originating from a copper-dependent oxidation of the 2-hydroxy catechol of estradiol. Carcinogenesis, Vol.15, No.7, (July 1994), pp. 1421-1427, ISSN 0143-3334

Monni, S., Uhlig, C., Junttila, O., Hansen, E., Hynynen, J. (2001). Chemical composition and ecophysiological responses of Empetrum nigrum to aboveground element application. Environmental Pollution, Vol.112, No.3, (May 2001), pp. 417-426, ISSN 0269-7491

Ouzounidou, G., Moustakas, M., Eleftheriou, E.P. (1997). Physiological and ultrastructural effects of cadmium on wheat (Triticum aestivum L.) leaves. Archives of Environmental Contamination and Toxicology, Vol.32, No.2, (February 1997), pp. 154-160, ISSN 00904341

Pahalawattaarachchi, V., Purushothaman, C.S., Vennila, A. (2009). Metal phytoremédiation potential of Rhizophora mucronata (Lam.). Indian Journal of Marine Sciences, Vol.38, No.2, (June 2009), pp. 178-183, ISSN 0379-5136

Parent, C., Capelli, N., Dat, J. (2008). Formes réactives de l'oxygène, stress et mort cellulaire chez les plantes. Comptes Rendus Biologies, Vol.331, No.4, (April 2008), pp. 255-261, ISSN 1631-0691

Paramesha, S., Vijay, R., Bekal, M., Kumari, S., Pushpalatha, K.C. (2011). A study on lipid peroxidation and total antioxidant status in diabetes with and without hypertension. Research Journal of Pharmaceutical, Biological and Chemical Sciences, Vol.2, No.1, (January-March 2011), pp. 329-334, ISSN 0975-8585

Pereira, G.J.G., Molina, S.M.G., Lea, P.J., Azevedo, R.A. (2002). Activity of antioxidant enzymes in response to cadmium in Crotalaria juncea. Plant and Soil, Vol.239, No.1, (January 2002), pp. 123-132, ISSN 0032-079X 
Qiu, J., Zhu, K., Zhang, J., Zhang, Z. (2002). Diversity of the microorganisms degrading aromatic hydrocarbons. Chinese Journal of Applied Ecology, Vol.13, No.12, (December 2002), pp. 1713-1715, ISSN 1001-9332

Ritter, L., Solomon, K., Sibley, P., Hall, K., Keen, P., Mattu, G., Linton, B. (2002). Sources, pathways, and relative risks of contaminants in surface water and groundwater: A perspective prepared for the Walkerton inquiry. Journal of Toxicology and Environmental Health - Part A, Vol.65, No.1, (January 2002), pp. 1-142, ISSN 15287394

Sacco, M.G., Amicone, L., Catò, EM., Filippini, D., Vezzoni, P., Tripodi, M. (2004). Cell-based assay for the detection of chemically induced cellular stress by immortalized untransformed transgenic hepatocytes. BMC Biotechnology, Vol.4, No.5, (March 2004), pp. 1-7, ISSN 1472-6750

Schwab, A.P. (2005). Pollutants: Organic and Inorganic, In: Encyclopedia of Soil Science, L. Rattan, (Ed.), 1334-1337, CRC Press, ISBN 978-0-8493-3830-4

Schaich, K.M. (2005). Lipid oxidation: theoretical aspects, In: Bailey's Industrial Oil and Fat Products, F. Shahidi, (Ed.), 269-355, Wiley J., Sons Publishers, ISBN 978-0-471-384601

Szarek-Łukaszewska, G., Słysz, A., Wierzbicka, M. (2004). Response of Armeria maritima (Mill.) Willd. to $\mathrm{Cd}, \mathrm{Zn}$ and $\mathrm{Pb}$. Acta Biologica Cracoviensia Series Botanica, Vol.46, No.1, (December 2004), pp. 19-24, ISSN 0001-5296

Tewari, R., Kumar, P., Sharma, P. (2005). Signs of oxidative stress in the chlorotic leaves of iron starved plants. Plant Science, Vol.169, No.6, (December 2005), pp. 1037-1045, ISSN 0168-9452

Thompson, J.E., Legge, R.L., Barber, R.F. (1987). The role of free radicals in senescence and wounding. New Phytologist, Vol.105, No.3, (March 1987), pp. 317-344, ISSN 0028646X

Van Breusegem, F., Dat, J.F. (2006). Reactive oxygen species in plant cell death. Plant Physiology, Vol.141, No.2, (June 2006), pp. 384-390, ISSN 0032-0889

Werner, T., Schmülling, T. (2009). Cytokinin action in plant development. Current Opinion in Plant Biology, Vol.12, No.5, (October 2009), pp. 527-538, ISSN 1369-5266

Xiao, S., Chye, M.-L. (2011). New roles for acyl-CoA-binding proteins (ACBPs) in plant development, stress responses and lipid metabolism. Progress in Lipid Research, Vol.50, No.2, (April 2011), pp. 141-151, ISSN 0163-7827

Xing, W., Huang, W., Liu, G. (2010). Effect of excess iron and copper on physiology of aquatic plant Spirodela polyrrhiza (L.) schleid. Environmental Toxicology, Vol.25, No.2, (April 2010), pp. 103-112, ISSN 1520-4081

Yasar, F., Uzal, O., Tufenkci, S., Yildiz, K. (2006). Ion accumulation in different organs of green bean genotypes grown under salt stress. Plant, Soil and Environment, Vol.52, No. 10, (October 2006), pp. 476-480, ISSN 1214-1178 


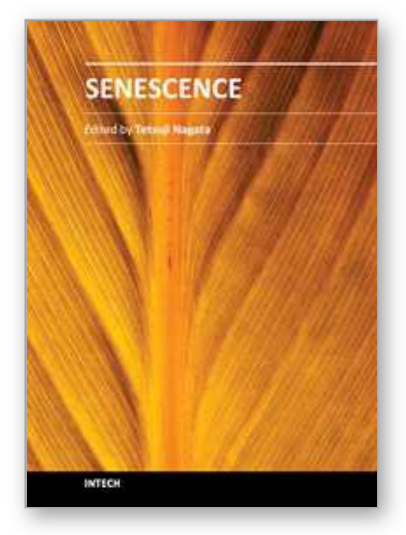

\author{
Senescence \\ Edited by Dr. Tetsuji Nagata
}

ISBN 978-953-51-0144-4

Hard cover, 850 pages

Publisher InTech

Published online 29, February, 2012

Published in print edition February, 2012

The book "Senescence" is aimed to describe all the phenomena related to aging and senescence of all forms of life on Earth, i.e. plants, animals and the human beings. The book contains 36 carefully reviewed chapters written by different authors, aiming to describe the aging and senescent changes of living creatures, i.e. plants and animals.

\title{
How to reference
}

In order to correctly reference this scholarly work, feel free to copy and paste the following:

David Delmail and Pascal Labrousse (2012). Plant Ageing, a Counteracting Agent to Xenobiotic Stress, Senescence, Dr. Tetsuji Nagata (Ed.), ISBN: 978-953-51-0144-4, InTech, Available from: http://www.intechopen.com/books/senescence/plant-ageing-a-counteracting-agent-to-xenobiotic-stress

\section{INTECH}

open science | open minds

\section{InTech Europe}

University Campus STeP Ri

Slavka Krautzeka 83/A

51000 Rijeka, Croatia

Phone: +385 (51) 770447

Fax: +385 (51) 686166

www.intechopen.com

\section{InTech China}

Unit 405, Office Block, Hotel Equatorial Shanghai

No.65, Yan An Road (West), Shanghai, 200040, China

中国上海市延安西路65号上海国际贵都大饭店办公楼405单元

Phone: +86-21-62489820

Fax: $+86-21-62489821$ 
(C) 2012 The Author(s). Licensee IntechOpen. This is an open access article distributed under the terms of the Creative Commons Attribution 3.0 License, which permits unrestricted use, distribution, and reproduction in any medium, provided the original work is properly cited. 